\title{
A COMPARATIVE STUDY OF PULMONARY FUNCTION TEST IN LAPAROTOMY AND LAPAROSCOPIC SURGERIES
}

\section{Surgery \\ Dr. Pallavi Ajankar* DNB Resident, RCSM GMC Kolhapur *Corresponding Author}

\section{ABSTRACT}

Background and Aims- Respiratory complications account to majority of post-operative outcomes after abdominal surgeries. Data on exact prevalence and probability after different surgeries is scanty. Aim of our study is to evaluate pre and post operative differences objectively by using spirometry in patients undergoing upper abdominal laparoscopic and laparotomy surgeries.

Methods- Seventy-one patients consecutively undergoing surgeries were enrolled, of which 36 underwent laparoscopic and rest open laparotomy. Patients were subjected to spirometry pre and post operatively, and FVC, FEV1, FEV1/FVC, VC were calculated. This cross sectional data was analysed using paired " $\mathrm{t}$ " test, Students " $\mathrm{t}$ " test and Chi square.

Results- Preoperative FEV1,ERV, TLC, PEFR were significantly better in laparotomy than laparoscopic group ( $\mathrm{p}$ value $<0.05$ ). Age, sex and BMI were not significant determinants. Post operatively the laparoscopic group had better outcomes than laparotomy group. The exact mechanisms were not known but minimal scar length, lesser damage to diaphragm and muscles, younger age of patients in laparoscopic group and early postoperative rehabilitation could be possible explanations

Conclusions- Present study demonstrates that laparoscopic surgeries has less adverse effects on postoperative pulmonary function than laparotomy surgeries. This may correlate with lower post op respiratory complications in laparoscopy group.

\section{KEYWORDS}

Laparoscopy, laparotomy, spirometry, respiratory complications

\section{INTRODUCTION}

Major abdominal surgery is associated with lung complications, which are usually more common in upper abdominal surgery than in lower abdominal surgery ${ }^{1}$. The incidence of the development of lung complications following major abdominal surgery is approximately $20-25 \%$ and the mortality rate of these complications is reported to be $3-4 \%$. In such cases, lung complications are considered to develop due to the incisional pain and inadequate ventilation, diaphragmatic dysfunction, and deterioration of the ventilation mechanism due to other reasons ${ }^{3}$. Laparoscopic abdominal surgery is considered to cause less pulmonary dysfunction than open abdominal surgery since it causes less incisional pain in the postoperative period and consequently has less effect on postoperative lung oxygenation ${ }^{1,3}$. While there are many studies that compared open and laparoscopic surgery regarding their pulmonary effects in procedures such as cholecystectomy, obesity surgery, esophagogastric surgery, and nephrectomy, there are very few such studies on colorectal surgeries.

Postoperative complications are now regarded as very important parameters for evaluation of surgical technique ${ }^{3}$. Pulmonary complications such as hypoxia, atelectasis, pulmonary embolism, and pneumonia can develop after major abdominal surgery ${ }^{5}$. The main known advantages of laparoscopic colorectal surgery over open surgery are a less postoperative pain, shorter hospitalization, and better cosmetic results.

Pulmonary function tests (PFTS) are an important tool in the investigation and monitoring of patients with respiratory pathology. They provide important information relating to the large and small airways, the pulmonary parenchyma and the size and integrity of the pulmonary capillary bed. Although they do not provide a diagnosis per se, different patterns of abnormalities are seen in various respiratory diseases which helps to establish a diagnosis ${ }^{8}$. Atelectasis and pneumonia are generally the most commonly developing pulmonary complications following major abdominal surgery ${ }^{1,9}$. Many studies have investigated the pulmonary complications of open and laparoscopic cholecystectomy, particularly after laparoscopic cholecystectomy became widespread in the early 1990s. Bablekos et al. reported that laparoscopic cholecystectomy gave better results when compared to open cholecystectomy in terms of respiratory functions and pulmonary respiratory physiopathology and that the complication rate was lower ${ }^{1}$. In another study, Boni et al. reported that the immune system was better preserved and there was less proinflammatory cytokine response in all laparoscopic surgical procedures; consequently, the infection rate, including the pulmonary system infections, was lower in laparoscopic surgery than in open surgery $^{10}$. Antoniou et al. reported that, in obesity surgery, the obesity itself was a pulmonary risk factor for complications in the postoperative period, together with parameters such as incisional pain, diaphragmatic irritation, and hypoventilation; they reported less pulmonary complications in their patients who had undergone laparoscopic surgery.

The suppression of pulmonary function is a well-known sequela of abdominal surgery and has been characterized as a restrictive pattern ${ }^{12,13}$. Following upper abdominal incisions, forced vital capacity (FVC) and forced expiratory volume in 1sec (FEV1) are reduced by approximately $60 \%$ because of a reflectory dysfunction of the diaphragm $^{14-18}$. The functional residual capacity (FRC) is decreased postoperatively and atelectasis occurs in most patients. ${ }^{14,1}$

PFTs can help diagnose ${ }^{20}$ Asthma, Allergies, Chronic bronchitis, Respiratory infections, Lung fibrosis, Bronchiectasis, a condition in which the airways in the lungs stretch and widen COPD, which used to be called emphysema, Asbestosis, a condition caused by exposure to asbestos, Sarcoidosis, an inflammation of your lungs, liver, lymph nodes, eyes, skin, or other tissues, Scleroderma, a disease that affects your connective tissue, Pulmonary tumor, Lung cancer, Weaknesses of the chest wall muscles

\section{MATERIALAND METHODS}

This study was done at Rajarshee Chatrapati Shahu Maharaj Government Medical College \& CPR Hospital, Kolhapur, and Maharashtra, India. It was a cross sectional study conducted at Department of surgery, RCSM GMC, Kolhapur, Maharashtra, India, from September 2017 to February 2019. The study was approved by Institutional ethics committee in August 2017.

Study had included all consecutive patients undergoing open and laparoscopic surgeries in surgery department of RCSM GMC, Kolhapur. Inclusion criteria were adults (aged 16 years - 55 years) of both sexes undergoing (laparoscopic and open) surgeries, such as cholecystectomy, hernia repair, elective spleenectomy, elective surgery, $\mathrm{ASA}<3$, no comorbid conditions. Patients with age $<16$ years and $>55$ years, pregnancy, emergency surgery, ASA $>3$, patients not willing for consent, mentally ill patients, co-morbidities like cardio respiratory disorders, hemodynamically unstable patient after surgery,chronic smokers were excluded.

Sampling size: - As per previous 3 years statistics there are $38 \%$ cases of laparotomy and $62 \%$ cases of laparoscopy ${ }^{42}$. With $5 \%$ allowable error and $90 \%$ power total sample size 71

$$
n=\frac{Z_{\alpha / 2}}{2 d^{2}} p q
$$

Where $\mathrm{Z} \alpha / 2$ is the critical value of the normal distribution at $\alpha / 2$ $\mathrm{p}=$ Sample proportion

$\mathrm{d}=$ Margin of error

$\mathrm{q}=1-\mathrm{p}$

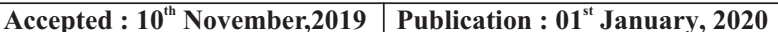


hence, 35 patients in laparotomy and 36 patients in laparoscopic group were enrolled. All selected subjects were briefed about the study. After detailed consent, patient's detailed history was elicited including medical history and history of drug allergy. Detailed clinical examination was done. All patients have been subjected to a detailed history regarding

a) Onset and progression of the disease

b) Type of surgery done and anesthesia given.

c) Pre and post-operative clinical and biochemical parameters

Pre and post-operative pulmonary function test assessment including forced vital capacity (FVC), forced expiratory volume in $1 \mathrm{~s} \mathrm{(FEV1),}$ peak expiratory flow (PEF), expiratory reserve volume (ERV), and the mid-expiratory phase of forced expiratory flow (FEF25-75\%). Imaging- pre \& postoperative Chest X-ray. Collected data was entered in the excel data sheet and data analysis was done with the help of Epi. Info version 7.2 software.

\section{- Measurement Tool definitions:}

- Tidal volume: This is the amount of air inhaled or exhaled during normal breathing.

- Minute volume (MV): This is the total amount of air exhaled per minute.

- Vital capacity (VC): This is the total volume of air that can be exhaled after inhaling as much as you can.

- Functional residual capacity (FRC): This is the amount of air left in lungs after exhaling normally.

- Forced expiratory flow (FEF): This is the average rate of flow during the middle half of the FVC test.

- Peak expiratory flow rate (PEFR): This is the fastest rate that you can force air out of your lung. Intra-abdominal operations are at relatively high risk for pulmonary complications. Purpose of this study is to study the effects of both laparotomy and laparoscopy on PFT.

\section{Statistical method:}

Data was cleaned, Validated and Analysed by Epi. Info 7 software. Descriptive Statistics: For continuous variable range, mean and standard deviation were calculated and for categorical variables proportion and percentage were obtained. Bi-Variate analysis: To know the association between dependent and independent variable chi-square, t-test applied accordingly.

RESULTS AND OBSERVATIONS

Table 2: Age distribution of study participants $(\mathrm{N}=71)$

\begin{tabular}{|c|c|c|}
\hline Age (in years) & $\begin{array}{c}\text { Laparotomy Group } \\
(\mathbf{n}=\mathbf{3 5})\end{array}$ & $\begin{array}{c}\text { Laparoscopic Group } \\
(\mathbf{n}=\mathbf{3 6})\end{array}$ \\
\hline $16-25$ & $3(8.6)$ & $2(5.6)$ \\
$26-35$ & $7(20.0)$ & $11(30.6)$ \\
$36-45$ & $12(34.3)$ & $14(38.8)$ \\
$46-55$ & $13(37.1)$ & $9(25.0)$ \\
\hline Mean Age \pm SD & $53.1 \pm 5.2$ & $51.9 \pm 4.8$ \\
\hline
\end{tabular}

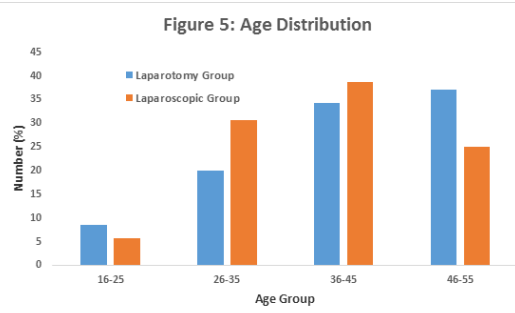

Table 3: Gender distribution of study participants $(\mathrm{N}=\mathbf{7 1})$

\begin{tabular}{|c|c|c|}
\hline Gender & $\begin{array}{c}\text { Laparotomy Group } \\
(\mathbf{n}=\mathbf{3 5})\end{array}$ & $\begin{array}{c}\text { Laparoscopic Group } \\
(\mathbf{n}=\mathbf{3 6})\end{array}$ \\
\hline Male & $21(60.0)$ & $19(52.8)$ \\
Female & $14(40.0)$ & $17(47.2)$ \\
\hline
\end{tabular}

Figure 6: Gender Distribution

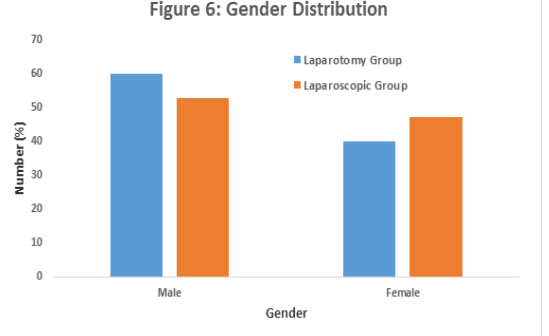

Table 4: BMI among study participants $(\mathrm{N}=71)$

\begin{tabular}{|c|c|c|}
\hline $\begin{array}{c}\text { BMI Class } \\
\text { (in weight in kg/height in } \mathbf{~ m t}^{2} \text { ) }\end{array}$ & $\begin{array}{c}\text { Laparotomy } \\
\text { Group (n=35) }\end{array}$ & $\begin{array}{c}\text { Laparoscopic } \\
\text { Group (n=36) }\end{array}$ \\
\hline$<18$ & $0(0.0)$ & $1(2.8)$ \\
$18-24.9$ & $14(40.0)$ & $16(44.4)$ \\
$25-29.9$ & $19(54.3)$ & $14(38.9)$ \\
$>30$ & $2(5.7)$ & $5(13.9)$ \\
\hline Mean BMI \pm SD & $28.5 \pm 3.3$ & $26.1 \pm 5.2$ \\
\hline
\end{tabular}

Figure 7: BMI Distribution

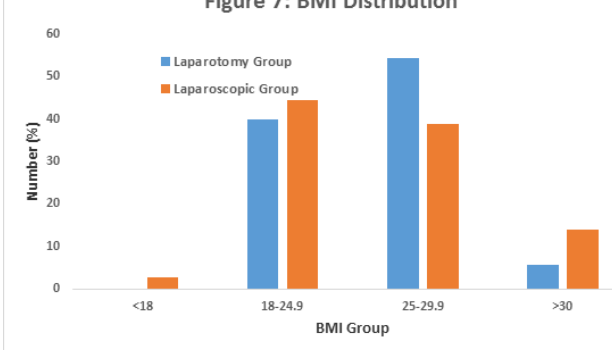

Table 5: Pre-operative FVC $(\mathrm{N}=71)$

\begin{tabular}{|c|c|c|c|}
\hline Variable & $\begin{array}{c}\text { Laparotomy } \\
\text { Group (n=35) }\end{array}$ & $\begin{array}{c}\text { Laparoscopic } \\
\text { Group (n=36) }\end{array}$ & $\begin{array}{c}\text { P } \\
\text { value* }^{*}\end{array}$ \\
\hline $\begin{array}{c}\text { Pre-operative FVC } \\
\text { value (L/s) }[\text { Mean } \pm \text { SD] }\end{array}$ & $3.5 \pm 0.8$ & $3.6 \pm 0.8$ & $<0.05$ \\
\hline
\end{tabular}

*-Student t Test

Figure 8: Pre-operative FVC

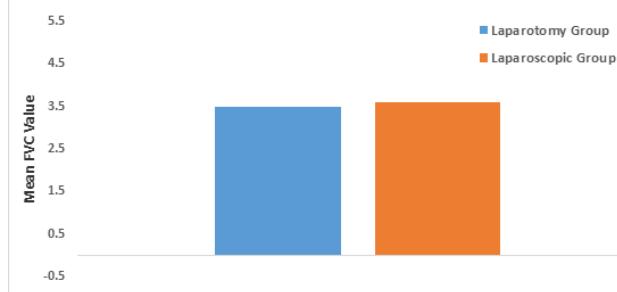

Pre-operative FEV1 $(\mathrm{N}=71)$

\begin{tabular}{|l|c|c|c|}
\hline \multicolumn{1}{|c|}{ Variable } & $\begin{array}{c}\text { Laparotomy } \\
\text { Group }(\mathbf{n = 3 5})\end{array}$ & $\begin{array}{c}\text { Laparoscopic } \\
\text { Group }(\mathbf{n = 3 6})\end{array}$ & $\begin{array}{c}\text { P } \\
\text { value* }^{*}\end{array}$ \\
\hline $\begin{array}{l}\text { Pre-operative FEV1 } \\
\text { value }(\mathrm{L} / \mathrm{s})[\mathrm{Mean} \pm \mathrm{SD}]\end{array}$ & $3.0 \pm 0.5$ & $3.1 \pm 0.7$ & $>0.05$ \\
\hline
\end{tabular}

* - Student t Test

Table 7: Pre-operative FEF25-75\%(N=71)

\begin{tabular}{|c|c|c|c|}
\hline Variable & $\begin{array}{c}\text { Laparotomy } \\
\text { Group (n=35) }\end{array}$ & $\begin{array}{c}\text { Laparoscopic } \\
\text { Group (n=36) }\end{array}$ & $\begin{array}{c}\text { P } \\
\text { value }^{*}\end{array}$ \\
\hline $\begin{array}{l}\text { Pre-operative FEF25-75\% } \\
\text { value (L/s) }[\text { Mean } \pm \text { SD] }\end{array}$ & $1.9 \pm 0.6$ & $2.0 \pm 0.8$ & $<0.05$ \\
\hline
\end{tabular}

*-Student t Test

Figure 10: Pre-operative FEF $^{25-75 \%}$

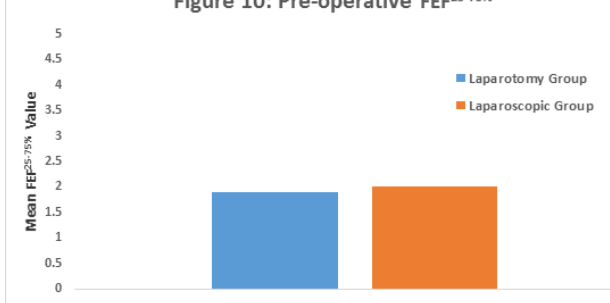

Pre-operative PEF $(\mathrm{N}=71)$

\begin{tabular}{|l|c|c|c|}
\hline \multicolumn{1}{|c|}{ Variable } & $\begin{array}{c}\text { Laparotomy } \\
\text { Group (n=35) }\end{array}$ & $\begin{array}{c}\text { Laparoscopic } \\
\text { Group (n=36) }\end{array}$ & $\begin{array}{c}\text { P } \\
\text { value* }^{*}\end{array}$ \\
\hline $\begin{array}{l}\text { Pre-operative PEF value } \\
(\mathrm{L} / \mathrm{s})[\text { Mean } \pm \text { SD] }\end{array}$ & $6.1 \pm 1.2$ & $5.9 \pm 1.4$ & $<0.05$ \\
\hline
\end{tabular}

* - Student t Test 
Figure 11: Pre-operative PEF

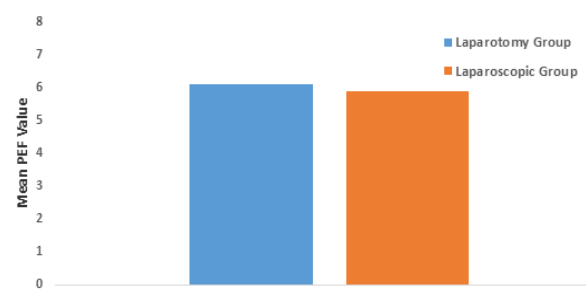

Table 9: Pre-operative ERV (N=71)

\begin{tabular}{|l|l|l|l|}
\hline \multicolumn{1}{|c|}{ Variable } & $\begin{array}{c}\text { Laparotomy } \\
\text { Group }(\mathbf{n}=35)\end{array}$ & $\begin{array}{c}\text { Laparoscopic } \\
\text { Group }(\mathbf{n = 3 6})\end{array}$ & $\begin{array}{c}\text { P } \\
\text { value* }\end{array}$ \\
\hline $\begin{array}{l}\text { Pre-operative ERV value } \\
(\mathrm{L} / \mathrm{s})[\text { Mean } \pm \mathrm{SD}]\end{array}$ & $1.2 \pm 0.6$ & $1.1 \pm 0.5$ & $>0.05$ \\
\hline
\end{tabular}

* - Student t Test

Figure 12: Pre-operative ERV

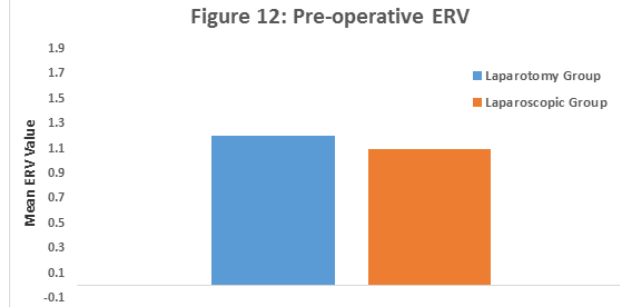

Table 10: Pre-operative TLC $(\mathrm{N}=71)$

\begin{tabular}{|l|c|c|c|}
\hline \multicolumn{1}{|c|}{ Variable } & $\begin{array}{c}\text { Laparotomy } \\
\text { Group (n=35) }\end{array}$ & $\begin{array}{c}\text { Laparoscopic } \\
\text { Group (n=36) }\end{array}$ & $\begin{array}{c}\text { P } \\
\text { value }^{*}\end{array}$ \\
\hline $\begin{array}{l}\text { Pre-operative TLC value } \\
(\mathrm{L} / \mathrm{s})[\text { Mean } \pm \text { SD] }\end{array}$ & $5.9 \pm 0.8$ & $5.8 \pm 0.9$ & $<0.05$ \\
\hline
\end{tabular}

* - Student t Test

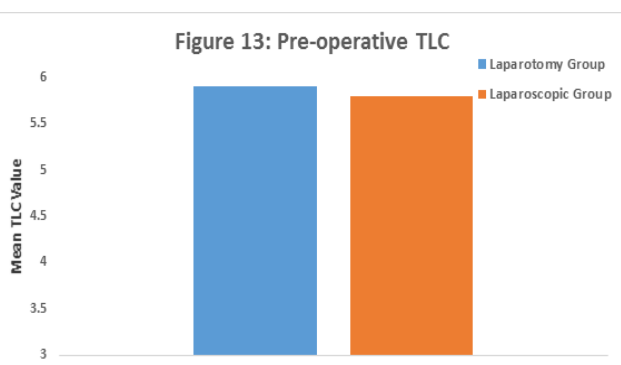

Table 11: Pre-operative ITGV $(\mathbf{N}=71)$

\begin{tabular}{|c|c|c|c|}
\hline \multicolumn{1}{|c|}{ Variable } & $\begin{array}{c}\text { Laparotomy } \\
\text { Group }(\mathbf{n = 3 5})\end{array}$ & $\begin{array}{c}\text { Laparoscopic } \\
\text { Group }(\mathbf{n = 3 6})\end{array}$ & $\begin{array}{c}\text { P } \\
\text { value* }^{*}\end{array}$ \\
\hline $\begin{array}{l}\text { Pre-operative ITGV value } \\
(\mathrm{L} / \mathrm{s})[\text { Mean } \pm \text { SD] }\end{array}$ & $3.5 \pm 0.9$ & $3.4 \pm 1.0$ & $>0.05$ \\
\hline
\end{tabular}

* - Student t Test

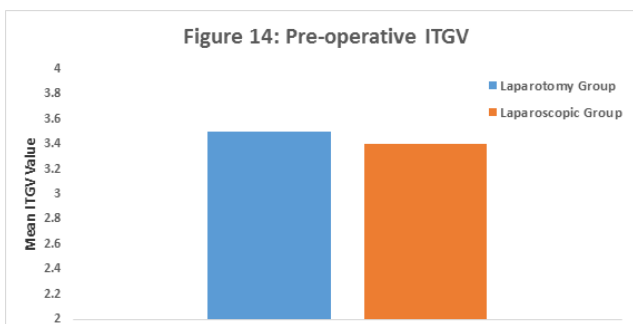

Table 12: Post-operative FVC $(\mathrm{N}=71)$

\begin{tabular}{|l|c|c|c|}
\hline \multicolumn{1}{|c|}{ Variable } & $\begin{array}{c}\text { Laparotomy } \\
\text { Group (n=35) }\end{array}$ & $\begin{array}{c}\text { Laparoscopic } \\
\text { Group (n=36) }\end{array}$ & $\begin{array}{c}\text { P } \\
\text { value* }\end{array}$ \\
\hline $\begin{array}{l}\text { Post-operative FVC value } \\
\text { (L/s) }[\text { Mean } \pm \text { SD }]\end{array}$ & $2.6 \pm 1.1$ & $3.1 \pm 0.6$ & $<0.05$ \\
\hline
\end{tabular}

\footnotetext{
* - Student t Test
}

Table 13: Post-operative FEV1 (N=71)

\begin{tabular}{|l|c|c|c|}
\hline \multicolumn{1}{|c|}{ Variable } & $\begin{array}{c}\text { Laparotomy } \\
\text { Group (n=35) }\end{array}$ & $\begin{array}{c}\text { Laparoscopic } \\
\text { Group (n=36) }\end{array}$ & $\begin{array}{c}\text { P } \\
\text { value* }^{*}\end{array}$ \\
\hline $\begin{array}{l}\text { Post-operative FEV1 } \\
\text { value (L/s) }[\text { Mean } \pm \text { SD] }\end{array}$ & $1.7 \pm 0.7$ & $2.4 \pm 0.5$ & $<0.05$ \\
\hline
\end{tabular}

* - Student t Test

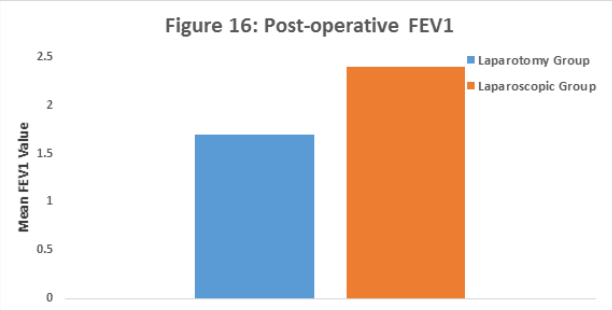

Table 14: Post-operative FEF25-75\% (N=)

\begin{tabular}{|c|c|c|c|}
\hline Variable & $\begin{array}{c}\text { Laparotomy } \\
\text { Group }(\mathbf{n}=35)\end{array}$ & $\begin{array}{c}\text { Laparoscopic } \\
\text { Group }(\mathbf{n}=36)\end{array}$ & $\begin{array}{c}\mathbf{P} \\
\text { value }^{*}\end{array}$ \\
\hline $\begin{array}{l}\text { Post-operative FEF25-75\% } \\
\text { value (L/s) }[\text { Mean } \pm \text { SD] }\end{array}$ & $1.3 \pm 0.7$ & $1.7 \pm 0.5$ & $>0.05$ \\
\hline
\end{tabular}

*-Student t Test

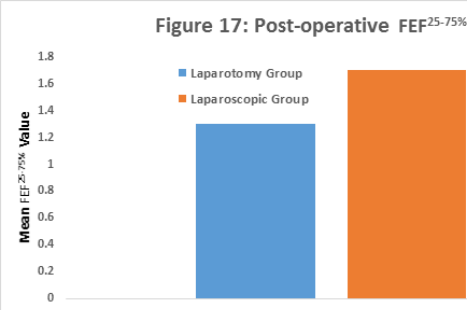

Table 15: Post-operative $\mathrm{PEF}(\mathrm{N}=71)$

\begin{tabular}{|l|c|c|c|}
\hline \multicolumn{1}{|c|}{ Variable } & $\begin{array}{c}\text { Laparotomy } \\
\text { Group }(\mathbf{n}=\mathbf{3 5})\end{array}$ & $\begin{array}{c}\text { Laparoscopic } \\
\text { Group }(\mathbf{n = 3 6})\end{array}$ & $\begin{array}{c}\text { P } \\
\text { value* }^{*}\end{array}$ \\
\hline $\begin{array}{l}\text { Post-operative PEF } \\
\text { value (L/s) }[\text { Mean } \pm \mathrm{SD}]\end{array}$ & $3.8 \pm 1.5$ & $4.9 \pm 1.2$ & $<0.05$ \\
\hline
\end{tabular}

*-Student t Test

Figure 18: Post-operative PEF

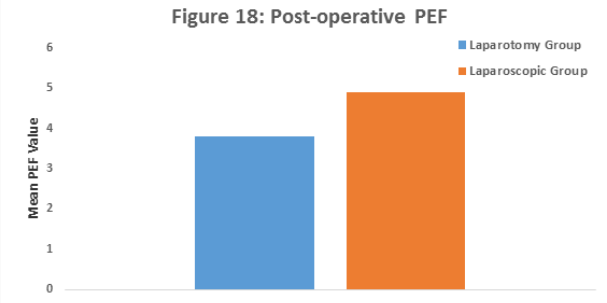

Table 16: Post-operative ERV (N=71)

\begin{tabular}{|l|c|c|c|}
\hline \multicolumn{1}{|c|}{ Variable } & $\begin{array}{c}\text { Laparotomy } \\
\text { Group (n=35) }\end{array}$ & $\begin{array}{c}\text { Laparoscopic } \\
\text { Group (n=36) }\end{array}$ & $\begin{array}{c}\text { P } \\
\text { value* }^{*}\end{array}$ \\
\hline $\begin{array}{l}\text { Post-operative ERV } \\
\text { value (L/s) }[\text { Mean } \pm \text { SD] }\end{array}$ & $0.8 \pm 0.3$ & $1.0 \pm 0.3$ & $<0.05$ \\
\hline
\end{tabular}

* - Student t Test

Figure 19: Post-operative ERV

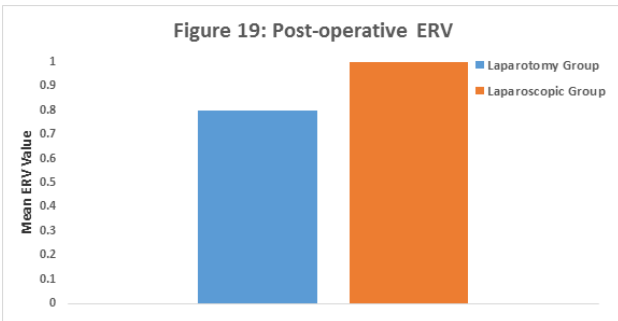


Table 17: Post-operative TLC $(\mathrm{N}=71)$

\begin{tabular}{|l|c|c|c|}
\hline \multicolumn{1}{|c|}{ Variable } & $\begin{array}{c}\text { Laparotomy } \\
\text { Group (n=35) }\end{array}$ & $\begin{array}{l}\text { Laparoscopic } \\
\text { Group (n=36) }\end{array}$ & $\begin{array}{c}\text { P } \\
\text { value* }^{*}\end{array}$ \\
\hline $\begin{array}{l}\text { Post-operative TLC value } \\
(\mathrm{L} / \mathrm{s})[\text { Mean } \pm \text { SD] }\end{array}$ & $5.2 \pm 0.7$ & $5.5 \pm 0.9$ & $<0.05$ \\
\hline
\end{tabular}

*-Student tTest

Figure 20: Post-operative TLC

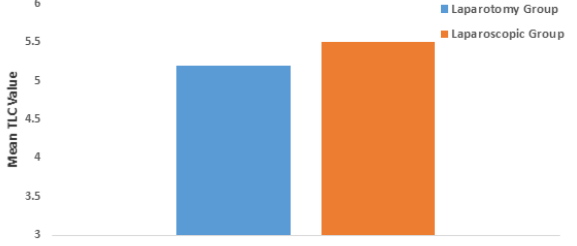

Table 18: Post-operative ITGV $(\mathrm{N}=71)$

\begin{tabular}{|l|c|c|c|}
\hline \multicolumn{1}{|c|}{ Variable } & $\begin{array}{c}\text { Laparotomy } \\
\text { Group }(\mathbf{n = 3 5})\end{array}$ & $\begin{array}{c}\text { Laparoscopic } \\
\text { Group (n=36) }\end{array}$ & $\begin{array}{c}\text { P } \\
\text { value* }^{*}\end{array}$ \\
\hline $\begin{array}{l}\text { Post-operative ITGV value } \\
(\mathrm{L} / \mathrm{s})[\text { Mean } \pm \text { SD] }\end{array}$ & $3.1 \pm 0.9$ & $3.1 \pm 0.8$ & $>0.05$ \\
\hline
\end{tabular}

* - Student t Test

Figure 21: Post-operative ITGV

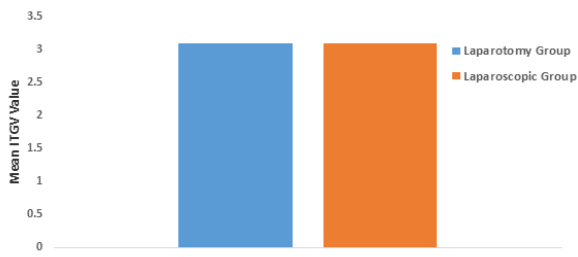

Table 19: Comparison of pre and post-operative value of pulmonary function test in laparotomy group $(\mathbf{N}=35)$

\begin{tabular}{|c|c|c|c|}
\hline Variable & Pre-operative Value & Post-operative Value & P value \\
\hline FVC & $3.5 \pm 0.8$ & $2.6 \pm 1.1$ & $<\mathbf{0 . 0 0 1}$ \\
\hline FEV1 & $3.0 \pm 0.5$ & $1.7 \pm 0.7$ & $<\mathbf{0 . 0 0 1}$ \\
\hline FEF $^{25-75 \%}$ & $1.9 \pm 0.6$ & $1.3 \pm 0.7$ & $<\mathbf{0 . 0 0 1}$ \\
\hline PEF & $6.1 \pm 1.2$ & $3.8 \pm 1.5$ & $<\mathbf{0 . 0 0 1}$ \\
\hline ERV & $1.2 \pm 0.6$ & $0.8 \pm 0.3$ & $<\mathbf{0 . 0 0 1}$ \\
\hline TLC & $5.9 \pm 0.8$ & $5.2 \pm 0.7$ & $<\mathbf{0 . 0 0 1}$ \\
\hline ITGV & $3.5 \pm 0.9$ & $3.1 \pm 0.9$ & $<\mathbf{0 . 0 0 1}$ \\
\hline
\end{tabular}

Table 20: Comparison of pre and post-operative value of pulmonary function test in laparoscopic group $(\mathrm{N}=36)$

\begin{tabular}{|c|c|c|c|}
\hline Variable & Pre-operative Value & Post-operative Value & P value \\
\hline FVC & $3.6 \pm 0.8$ & $3.1 \pm 0.6$ & $<\mathbf{0 . 0 0 1}$ \\
\hline FEV1 & $3.1 \pm 0.7$ & $2.4 \pm 0.5$ & $<\mathbf{0 . 0 0 1}$ \\
\hline FEF $^{25-75 \%}$ & $2.0 \pm 0.8$ & $1.7 \pm 0.5$ & $<\mathbf{0 . 0 0 1}$ \\
\hline PEF & $5.9 \pm 1.4$ & $4.9 \pm 1.2$ & $<\mathbf{0 . 0 0 1}$ \\
\hline ERV & $1.1 \pm 0.5$ & $1.0 \pm 0.3$ & $>\mathbf{0 . 0 5}$ \\
\hline TLC & $5.8 \pm 0.9$ & $5.5 \pm 0.9$ & $<\mathbf{0 . 0 0 1}$ \\
\hline ITGV & $3.4 \pm 1.0$ & $3.1 \pm 0.8$ & $<\mathbf{0 . 0 0 1}$ \\
\hline
\end{tabular}

\section{DISCUSSION}

The etiology of pulmonary dysfunction after upper abdominal surgery is not completely understood, and multiple factors may contribute. Pulmonary function is more depressed after incisions in the upper abdomen than after lower abdominal laparotomy. ${ }^{12-17}$ Upper abdominal surgeries produce significant changes in pulmonary function, including a reduction in vital capacity, FEV1, PEF, and functional residual capacity. Postoperative pulmonary dysfunction has primarily been considered a restrictive process. The ratio FEV1/FVC helps to distinguish between obstructive and restrictive abnormalities. In patients with obstructive limitations, the FEV1/FVC ratio is reduced, but in patients with restrictive disease the ratio is normal or increased. These changes may lead to the development of atelectasis, hypoxemia, and pneumonia. Table 2 and figure 5 shows that 37.1\%, 34.3\%, 20.0\% $\& 8.6 \%$ participants were belonged to age group of $46-55,36-45,26-$ $35 \& 16-25$ respectively in laparotomy group. In laparoscopic group, $25.0 \%, 38.8 \%, 30.6 \% \& 5.6 \%$ were belonged to age group of $46-55$,
36-45, 26-35 \& 16-25 respectively. Mean age of participants was 53.1 \pm 5.2 years \& $51.9 \pm 4.8$ years in the group of laparotomy \& laparoscopic group respectively. Ageing process is associated with progressive constriction of the homeostatic reserve of every organ. The most important physiological changes associated with ageing are of respiratory system depicting the decrease in static elastic recoil of the lung, in respiratory muscle performance, and in compliance of the chest wall and respiratory system, resulting in increased work of breathing $^{43}$. Lung functions decline throughout adult life, even in healthy persons. Cross sectional analysis has suggested that the decline may go faster after age 70 . Normal aging results in changes in pulmonary, mechanics, respiratory muscle strength, gas exchange and ventilatory control. Increased rigidity of chest wall and a decrease in respiratory muscle strength with aging result in an increased closing capacity and a decreased forced expiratory volume in first second or FEV1 $1^{44,45}$. These findings are correlate with the study done by Hasukic et $\mathrm{al}^{34} \&$ Freeman JA et $\mathrm{al}^{36}$ but not comparable with the study done by Celik S et al; \& Schwenk W et al ${ }^{7,35}$ where mean age was higher in both the group. Table 3 and figure 6 shows that $60.0 \% \& 40.0 \%$ participants were male $\&$ female respectively in laparotomy group. In laparoscopic group, $52.8 \%$ \& $47.2 \%$ were male \& female participants respectively.It is well established that women exhibit several anatomic and physiologic characteristics that distinguish their responses to exercise from those of men. These factors have been shown to influence the training response and contribute to lower maximal aerobic power in women. Additionally, the reproductive hormones, estrogen and progesterone, can influence ventilation, substrate metabolism, thermoregulation, and pulmonary function during exercise. Pulmonary structural and morphologic differences between genders include smaller vital capacity and maximal expiratory flow rates, reduced airway diameter, and a smaller diffusion surface than age- and height-matched men. These differences may have an effect on the integrated ventilatory response, respiratory muscle work, and in pulmonary gas exchange during exercise. Specifically, recent evidence suggests that during heavy exercise, women demonstrate greater expiratory flow limitation, an increased work of breathing, and perhaps greater exercise induced arterial hypoxemia compared to men. The consequence of these pulmonary effects has the potential to adversely affect aerobic capacity and exercise tolerance in women. ${ }^{46}$ Table 4 and figure 7 shows that $0.0 \%, 40.0 \%, 54.3 \%$ \& $5.7 \%$ participants were belonged to BMI group of $<18,18-24.9,25-29.9$ $\&>30$ respectively in laparotomy group. In laparoscopic group, $2.8 \%$, $44.4 \%, 38.9 \%$ \& $13.9 \%$ were belonged to BMI group of $<18,18-24.9$, $25-29.9 \&>30$ respectively. Mean BMI of participants was $28.5 \pm 3.3 \&$ $26.1 \pm 5.2$ in the group of laparotomy \& laparoscopic group. There may be a causal association between asthma and obesity as obesity precedes the development of asthma. It has been seen that surgical and dietinduced weight loss interventions improves lung function and symptoms of asthma. Previous studies showed that the association between asthma and obesity was stronger in females than males ${ }^{47-52}$. The effects of obesity on spirometric values are not consistent in most of the studies, some studies showing no effects ${ }^{53-56}$ and some other studies showing significant effects ${ }^{57-61}$. This discrepancy between studies could be explained by the wide variations in ethnicity of different population in PFT values or this may be a result of methodological differences in these studies. A study ${ }^{62}$ reported increase in FEV1/FVC with increasing BMI among the subjects including asthmatics, which suggested the restrictive effects of BMI. The difference in respiratory function after laparoscopic and open surgeries cannot be explained by differences in anesthesia, duration of operation, or postoperative care in patients. Several other mechanisms may be responsible for the marked depression of pulmonary function after upper abdominal surgery, including surgical incision, local abdominal pain, and diaphragm dysfunction ${ }^{13,16,63,64}$. After upper abdominal surgery, diaphragmatic excursion is decreased, and paradoxical motion of the diaphragm may occur, which leads to increased demand on intercostal muscle contribution to respiration ${ }^{64}$. Diaphragm dysfunction after upper abdominal surgery is related to pain, an increase in abdominal wall tone, and phrenic stimulation due to local irritation of the gallbladder ${ }^{13}$. The site of surgical incision and transection of abdominal muscles has been demonstrated to have a major impact on depressed pulmonary function after abdominal surgery. ${ }^{13,15,17,18}$ Table 5 and figure $\mathbf{8}$ shows that mean Pre-operative FVC value was $3.5 \pm 0.8 \mathrm{~L} / \mathrm{s} \& 3.6 \pm 0.8 \mathrm{~L} / \mathrm{sin}$ laparotomy \& laparoscopic group respectively. The difference was statistically significant $(\mathrm{p}<0.05)$. Table 12 and figure 15 shows that mean Postoperative FVC value was $2.6 \pm 1.1 \mathrm{~L} / \mathrm{s} \& 3.1 \pm 0.6 \mathrm{~L} / \mathrm{s}$ in laparotomy \& laparoscopic group respectively. The difference was statistically 
significant $(\mathrm{p}<0.05)$. Present study findings observed the statistically significant higher FVC value in laparoscopic group than laparotomy group individuals. In post-operative period, significant higher FVC value in laparoscopic group than laparotomy group individuals. In both the group, FVC value statistically significant more suppressed during post-operative period in laparotomy group than laparoscopic group.During laparoscopic surgery, lung volume and pulmonary compliance are reduced and peak airway pressure is increased. The diaphragm is displaced upward by increased intra-abdominal pressure, which results in a reduction in the functional residual capacity, with a ventilation-perfusion mismatch, and carbon dioxide absorption aggravates hypercapnia ${ }^{65}$. In addition, laparoscopic surgery is more advantageous for postoperative pulmonary function recovery than laparotomy; however, postoperative $\mathrm{FVC}$ and FEV1 are decreased even in laparoscopic surgery ${ }^{34,66,67}$. Tajima et al. found that the FVC (\%) results of preoperative spirometry tests were helpful for predicting postoperative pneumonia development in patients who underwent colorectal surgery ${ }^{68}$. In another study, routine preoperative spirometry tests were useful for predicting PPC incidence after abdominal surgery $^{69}$. In contrast to these results, Huh et al. reported that preoperative spirometry findings could not be used to stratify the risk of PPC in elderly patients undergoing laparoscopic gastrectomy ${ }^{70}$ These conflicting results may be explained by the fact that PPC is affected by various factors, such as surgery type (laparotomy vs. laparoscopy), surgical site (upper or lower abdomen), intraoperative ventilator care strategy, postoperative lung care strategy, and other patient characteristics ${ }^{1}$. Study done by Oh TK et al demonstrated that lower $\mathrm{FVC} \%$ was related to the PPC-development risk among those patients undergoing laparoscopic abdominal surgery who were at a high risk of these complications preoperatively ${ }^{67}$. Table 6 and figure 9 shows that mean Pre-operative FEV1 value was $3.0 \mathrm{~L} / \mathrm{s}$ with $0.5 \mathrm{SD} \&$ $3.1 \mathrm{~L} / \mathrm{s}$ with $0.7 \mathrm{SD}$ in laparotomy \& laparoscopic group respectively. The difference was statistically not significant ( $p>0.05)$. Table 13 and figure 16 shows that mean Post -operative FEV1 value was $1.7 \pm 0.7 \mathrm{~L} / \mathrm{s}$ $\& 2.4 \pm 0.5 \mathrm{~L} / \mathrm{s}$ in laparotomy \& laparoscopic group respectively. The difference was statistically significant $(p<0.05)$. Present study findings observed the statistically not significant higher FEV1 value in laparoscopic group than laparotomy group individuals. In postoperative period, significant higher FEV1 value in laparoscopic group than laparotomy group individuals. The FEV1 value very much decreased in laparotomy group in compare to laparoscopic group individuals. In both the group, FEV1 value statistically significant more suppressed during post-operative period in laparotomy group than laparoscopic group. Table 7 and figure 10 shows that mean Preoperative $\mathrm{FEF}^{25-75 \%}$ value was $1.9 \mathrm{~L} / \mathrm{s}$ with $0.6 \mathrm{SD} \& 2.0 \mathrm{~L} / \mathrm{s}$ with $0.8 \mathrm{SD}$ in laparotomy \& laparoscopic group respectively. The difference was statistically significant $(\mathrm{p}<0.05)$. Table 14 and figure 17 shows that mean Post-operative $\mathrm{FEF}^{25-75 \%}$ value was $1.3 \mathrm{~L} / \mathrm{s}$ with $0.7 \mathrm{SD} \& 1.7 \mathrm{~L} / \mathrm{s}$ with $0.5 \mathrm{SD}$ in laparotomy \& laparoscopic group respectively. The difference was statistically not significant $(p>0.05)$. Present study findings observed slightly higher $\mathrm{FEF}^{25-75 \%}$ value in laparoscopic group than laparotomy group individuals. In post-operative period, higher $\mathrm{FEF}^{25-75 \%}$ value in laparoscopic group than laparotomy group individuals. In both the group, $\mathrm{FEF}^{25.75 \%}$ value statistically significant more suppressed during post-operative period in laparotomy group than laparoscopic group. But this difference in $\mathrm{FEF}^{25.75 \%}$ value in pre \& post-operative period among study groups was statistically not significant. Similar findings were also observed in the study done by HasukicS et al \& Schauer PR et al ${ }^{18,34}$. Table 8 and figure 11 shows that mean Pre-operative PEF value was $6.1 \pm 1.2 \mathrm{~L} / \mathrm{s} \& 5.9 \pm 1.4 \mathrm{~L} / \mathrm{s}$ in laparotomy \& laparoscopic group respectively. The difference was statistically significant $(\mathrm{p}<0.05)$. Table 15 and figure 18 shows that mean Post -operative PEF value was $3.8 \pm 1.5 \mathrm{~L} / \mathrm{s} \& 4.9 \pm 1.2 \mathrm{~L} / \mathrm{s}$ in laparotomy \& laparoscopic group respectively. The difference was statistically significant $(\mathrm{p}<0.05)$. Present study findings observed the statistically significant lower PEF value in laparoscopic group than laparotomy group individuals. In post-operative period, significant higher PEF value in laparoscopic group than laparotomy group individuals. In both the group, PEF value statistically significant more suppressed during post-operative period in laparotomy group than laparoscopic group. And this difference in PEFvalue in pre \& postoperative period among study groups was statistically significant. Lai $\mathrm{Y}$ et al observed that low PEF suggested poor respiratory muscle strength and lung function, and may be correlated with the occurrence of post-operative complications (PPCs) after surgery. They observed that PEF value were found statistically significant lower in PPCs group and via multivariate logistic regression analysis and PEF was significant independent predictors for the occurrence of PPCs.
Significant correlation between a low PEF value and PPCs in surgical patients, indicating a low PEF as independent risk factor for the occurrence of PPCs and a PPC-guided (PEF value $\leq 300 \mathrm{~L} / \mathrm{min}$ ) risk assessment could be meaningful for the pre-operative management of patients waiting for surgery ${ }^{72}$. Table 9 and figure 12 shows that mean Pre-operative ERV value was $1.2 \mathrm{~L} / \mathrm{s}$ with $0.6 \mathrm{SD} \& 1.1 \mathrm{~L} / \mathrm{s}$ with $0.5 \mathrm{SD}$ in laparotomy \& laparoscopic group respectively. The difference was statistically not significant ( $p>0.05$ ). Table 16 and figure 19 shows that mean Post-operative ERV value was $0.8 \mathrm{~L} / \mathrm{s}$ with $0.3 \mathrm{SD} \& 1.0 \mathrm{~L} / \mathrm{s}$ with $0.3 \mathrm{SD}$ in laparotomy \& laparoscopic group respectively. The difference was statistically significant $(\mathrm{p}<0.05)$. Present study findings observed the lower ERV value in laparoscopic group than laparotomy group individuals but the difference was statistically not significant. In post-operative period, significant higher ERV value in laparoscopic group than laparotomy group individuals. In both the group, ERV value statistically significant more suppressed during post-operative period in laparotomy group than laparoscopic group. And this difference in ERVvalue in pre \& post-operative period among study groups was statistically significant. Similar findings were also observed in the study done by HasukicS et $\mathrm{al}^{34} \&$ Schauer PR et $\mathrm{al}^{18}$. Table 10 and figure 13 shows that mean Pre-operative TLC value was $5.9 \mathrm{~L} / \mathrm{s}$ with $0.8 \mathrm{SD} \& 5.8 \mathrm{~L} / \mathrm{s}$ with $0.9 \mathrm{SD}$ in laparotomy \& laparoscopic group respectively. The difference was statistically significant $(\mathrm{p}<0.05)$. Table 17 and figure 20 shows that mean Postoperative TLC value was $5.2 \mathrm{~L} / \mathrm{s}$ with $0.7 \mathrm{SD} \& 5.5 \mathrm{~L} / \mathrm{s}$ with $0.9 \mathrm{SD}$ in laparotomy \& laparoscopic group respectively. The difference was statistically significant $(\mathrm{p}<0.05)$

Present study findings observed the statistically significant lower TLC value in laparoscopic group than laparotomy group individuals. In post-operative period, statistically significant slightly lower TLC value in laparoscopic group than laparotomy group individuals. In both the group, TLC value statistically significant less decreased during post-operative period in laparoscopic group than laparotomy group. And this difference in TLCvalue in pre \& post-operative period among study groups was statistically significant. Similar results were found in the study done by HasukicS et $\mathrm{al}^{34}$, Putensen HG et $\mathrm{al}^{17} \&$ Schauer PR et $\mathrm{al}^{18}$. After abdominal surgery, there is decrease in the value of TLC due to diaphragmatic dysfunction and increased abdominal muscle activity. ${ }^{36}$ Table 11 and figure 14 shows that mean Pre-operative ITGV value was $3.5 \mathrm{~L} / \mathrm{s}$ with $0.9 \mathrm{SD} \& 3.4 \mathrm{~L} / \mathrm{s}$ with 1.0 $\mathrm{SD}$ in laparotomy \& laparoscopic group respectively. The difference was statistically not significant $(\mathrm{p}>0.05)$. Table 18 and figure 21 shows that mean Post-operative ITGV value was $3.1 \mathrm{~L} / \mathrm{s}$ with 0.9 SD \& $3.1 \mathrm{~L} / \mathrm{s}$ with $0.8 \mathrm{SD}$ in laparotomy \& laparoscopic group respectively. The difference was statistically not significant $(\mathrm{p}>0.05)$. Present study findings observed the statistically significant lower ITGV value in laparoscopic group than laparotomy group individuals. In postoperative period, study observed same value of ITGC in laparoscopic group and laparotomy group individuals but this was statistically not significant. Table 19 shows that in laparotomy group, FVC value was $3.5 \mathrm{~L} / \mathrm{s}$ with $0.8 \mathrm{SD}$ and $2.6 \mathrm{~L} / \mathrm{s}$ with $1.1 \mathrm{SD}$ in pre-operative \& postoperative period and this difference was statistically significant $(\mathrm{p}<0.05)$. FEV1 value was $3.0 \mathrm{~L} / \mathrm{s}$ with $0.5 \mathrm{SD}$ and $1.7 \mathrm{~L} / \mathrm{s}$ with $0.7 \mathrm{SD}$ in pre-operative \& post-operative period and this difference was statistically significant $(\mathrm{p}<0.05)$. $\mathrm{FEF}^{25-75 \%}$ value was $1.9 \mathrm{~L} / \mathrm{s}$ with 0.6 $\mathrm{SD}$ and $1.3 \mathrm{~L} / \mathrm{s}$ with $0.7 \mathrm{SD}$ in pre-operative $\&$ post-operative period and this difference was statistically significant $(\mathrm{p}<0.05)$. PEF value was $6.1 \mathrm{~L} / \mathrm{s}$ with $1.2 \mathrm{SD}$ and $3.8 \mathrm{~L} / \mathrm{s}$ with $1.5 \mathrm{SD}$ in pre-operative \& post-operative period and this difference was statistically significant $(\mathrm{p}<0.05)$. ERV value was $1.2 \mathrm{~L} / \mathrm{s}$ with $0.6 \mathrm{SD}$ and $0.8 \mathrm{~L} / \mathrm{s}$ with $0.3 \mathrm{SD}$ in pre-operative \& post-operative period and this difference was statistically significant $(\mathrm{p}<0.05)$. TLC value was $5.9 \mathrm{~L} / \mathrm{s}$ with $0.8 \mathrm{SD}$ and $5.2 \mathrm{~L} / \mathrm{s}$ with $0.7 \mathrm{SD}$ in pre-operative $\&$ post-operative period and this difference was statistically significant $(\mathrm{p}<0.05)$. ITGV value was $3.5 \mathrm{~L} / \mathrm{s}$ with $0.9 \mathrm{SD}$ and $3.1 \mathrm{~L} / \mathrm{s}$ with $0.9 \mathrm{SD}$ in pre-operative \& postoperative period and this difference was statistically significant $(\mathrm{p}<0.05)$. Table 20 shows that in laparoscopic group, $\mathrm{FVC}$ value was $3.6 \mathrm{~L} / \mathrm{s}$ with $0.8 \mathrm{SD}$ and $3.1 \mathrm{~L} / \mathrm{s}$ with $0.6 \mathrm{SD}$ in pre-operative \& postoperative period and this difference was statistically significant $(\mathrm{p}<0.05)$. FEV1 value was $3.1 \mathrm{~L} / \mathrm{s}$ with $0.7 \mathrm{SD}$ and $2.4 \mathrm{~L} / \mathrm{s}$ with $0.5 \mathrm{SD}$ in pre-operative \& post-operative period and this difference was statistically significant $(\mathrm{p}<0.05)$. $\mathrm{FEF}^{25-75 \%}$ value was $2.0 \mathrm{~L} / \mathrm{s}$ with 0.8 $\mathrm{SD}$ and $1.7 \mathrm{~L} / \mathrm{s}$ with $0.5 \mathrm{SD}$ in pre-operative \& post-operative period and this difference was statistically significant $(\mathrm{p}<0.05)$. PEF value was $5.9 \mathrm{~L} / \mathrm{s}$ with $1.4 \mathrm{SD}$ and $4.9 \mathrm{~L} / \mathrm{s}$ with $1.2 \mathrm{SD}$ in pre-operative \& post-operative period and this difference was statistically significant $(\mathrm{p}<0.05)$. ERV value was $1.1 \mathrm{~L} / \mathrm{s}$ with $0.5 \mathrm{SD}$ and $1.0 \mathrm{~L} / \mathrm{s}$ with $0.3 \mathrm{SD}$ in 
pre-operative \& post-operative period and this difference was statistically not significant $(\mathrm{p}>0.05)$. TLC value was $5.8 \mathrm{~L} / \mathrm{s}$ with 0.9 $\mathrm{SD}$ and $5.5 \mathrm{~L} / \mathrm{s}$ with $0.9 \mathrm{SD}$ in pre-operative \& post-operative period and this difference was statistically significant $(\mathrm{p}<0.05)$. ITGV value was $3.4 \mathrm{~L} / \mathrm{s}$ with $1.0 \mathrm{SD}$ and $3.1 \mathrm{~L} / \mathrm{s}$ with $0.8 \mathrm{SD}$ in pre-operative \& post-operative period and this difference was statistically significant $(p<0.05)$. These results show that parameters of pulmonary function test of participants of laparotomy group were more reduced in postoperative period compare to participants of laparoscopic group.

\section{CONCLUSION}

In our study, Highest number of participants belonged to age group of 46 to 55 years in laparotomy group and to age group in 36 to 45 years in laparoscopic group. Mean age of participants was 53.1 years \& 51.9 years in the group of laparotomy \& laparoscopic group.Mean BMI of participants was 28.5 weight in $\mathrm{kg} /$ height in $\mathrm{mt}^{2} \& 26.1$ weight in $\mathrm{kg}$ /height in $\mathrm{mt}^{2}$ in the group of laparotomy \& laparoscopic group. FVC value statistically significant more suppressed during postoperative period in laparotomy group than laparoscopic group. FEV1 value statistically significant more suppressed during post-operative period in laparotomy group than laparoscopic group.PEF value statistically significant more suppressed during post-operative period in laparotomy group than laparoscopic group. ERV value statistically significant more suppressed during post-operative period in laparotomy group than laparoscopic group. TLC value statistically significant more suppressed during post-operative period in laparotomy group than laparoscopic group. Present study demonstrates that laparoscopic surgeries has less adverse effects on postoperative pulmonary function than laparotomy surgeries.

\section{REFERENCES}

. Bablekos GD, Michaelides SA, Analitis A, Charalabopoulos KA: Effcts of laparoscopic cholecystectomy on lung function: A systematic review. World J Gastroenterol, 2014; 20(46): 17603-17.

2. Hall JC, Tarala RA, Hall JL, Mander J: A multivariate analysis of the risk of pulmonary complications after laparotomy. Chest, 1991; 99: 923-27.

Yildırım O, Ayser F, Arıkan S et al: The comparison of pulmonary functions in open versus laparoscopic cholecystectomy. J Pak Med Assoc, 2009; 51(4):201-4.

4. Koc A, Inan G, Bozkirli F et al: The evaluation of pulmonary function and blood gas analysis in patients submitted to laparoscopic versus open nephrectomy. Int Braz J Urol, 2015;41(6): 1202-8

5. Berggren U, Gordh T, Grama D et al: Laparoscopic versus open cholecystectomy: Hospitalization, sick leave, analgesia and trauma responses. Br J Surg, 1994; 81 : 1362-65.

6. Y1lmaz EM, Cartı EB, Kandemir A: Our experience of laparoscopic colorectal surgery: Short term outcomes. Turk J Colorectal Dis, 2016; 26: 108-12.

Celik S, Yilmaz EM. Effcts of Laparoscopic and Conventional Methods on Lung Functions in Colorectal Surgery. Med Sci Monit, 2018;24:3244-3248.

8. Ranu H, Wilde M, Madden B. Pulmonary function tests. Ulster Med J 2011;80(2):84-90.

Lakshminarasimhachar A, Smetana GW: Preoperative evaluation: Estimation of pulmonary risk. Anesthesiol Clin, 2016;34(1): 71-88.

10. Boni L, Benevento A, Rovera F et al: Infective complications in laparoscopic surgery. Surg Infect (Larchmt), 2006; 7(Suppl. 2): S109-11.

11. Antoniou SA, Antoniou GA, Koch OO et al: Laparoscopic versus open obesity surgery: A meta-analysis of pulmonary complications. Dig Surg, 2015;32(2): 98-107

12. Coelho JCU, de Araujo RPM, Marchesini JB, Izabel Coelho CMM, de Araujo LRR. Pulmonary function after cholecystectomy performed through Kochers incision, a miniincision, and laparotomy. World J Surg, 1993;17: 544-546.

13. Joris J, Kaba A, Lamy M. Postoperative spirometry after laparoscopy for lower abdominal or upper abdominal surgical procedures. Br JAnaesth, 1997;79:422.

14. Ali J, Gana TJ. Lung volumes $24 \mathrm{~h}$ after laparoscopic cholecystectomy-justification for early discharge. Can Respir J, 1998; 5: 109-113.

15. Frazze RC, Roberts JW, Okeson GC, Symmonds RE, Snyder SK, Hendricks JC, Smith RW. Open versus laparoscopic cholecystectomy. A comparison of postoperative pulmonary function. Ann Surg, 1991;213: 651-653.

16. Karayiannakis AJ, Makri GG, Mantzioka A, Karousos D, Karatsaz G. Postoperative pulmonary function after laparoscopic and open cholecystectomy. Br J Anaesth, 1996; $77: 448-452$.

17. Putensen HG, Putensen C, Lammer H, Lingnau W, Aigner F, Benzer H. Comparison of postoperative respiratory function after laparoscopy or open laparotomy for cholecystectomy. Anesthesiology, 1992; 77:675-680.

18. Schauer PR, Luna J, Ghiatas AA, Glen ME, Warren JM, Sirinek KM. Pulmonary function after laparoscopic cholecystectomy. Surgery, 1993; 114: 398-397.

19. Torrington KG, Bilello JF, Hopkins TK, Hall EA Jr. Postoperative pulmonary changes after laparoscopic cholecystectomy. Southern Med J, 1996; 89: 675-678.

20. Martel J. Pulmonary function test. Healthline. 2017. [Available from: https://www.healthline.com/health/pulmonary-function-tests] [Accessed on 5th April, 2019]

21. Miller MR, Crapo R, Hankinson J, Brusasco V, Burgos F, Casaburi R. General considerations for lung function testing. Eur Respir J. 2005; 26(1):153-61.

22. Pellegrino R, Viegi G, Brusasco V, Crapo RO, Burgos F, Casaburi R. Interpretative strategies for lung function tests. Eur Respir J. 2005;26(5):948-68.

23. Macintyre N, Crapo RO, Viegi G, Johnson DC, van der Grinten CP, Brusasco V. Standardisation of the single-breath determination of carbon monoxide uptake in the lung. Eur Respir J. 2005; 26(4):720-35.

24. Wanger J, Clausen JL, Coates A, Pedersen OF, Brusasco V, Burgos F. Standardisation of the measurement of lung volumes. Eur Respir J. 2005;26(3):511-22.

25. Miller MR, Hankinson J, Brusasco V, Burgos F, Casaburi R, Coates A. Standardisation of spirometry. Eur Respir J. 2005;26(2):319-38.

26. Lung function testing: selection of reference values and interpretative strategies. American Thoracic Society. Am Rev Respir Dis. 1991;144(5):1202-18.

27. Wilde M, Nair S, Madden B. Pulmonary function tests-a review. Care of the Crit Ill. 2007; Dec 23(6):173-7.

28. Fabbri L, Pauwels RA, Hurd SS. Global Strategy for the Diagnosis, Management, and
Prevention of Chronic Obstructive Pulmonary Disease: GOLD Executive Summary updated 2003. COPD. 2004:1(1):105-41; discussion 103-4

29. Ranu H, Madden B A is for airway. BMJ 2010:340:c2367.

30. Evans JA, Whitelaw WA. The assessment of maximal respiratory mouth pressures in adults. Respir Care. 2009; 54(10):1348-59.

31. ATS/ERS Statement on respiratory muscle testing. American Thoracic Society/ European Respiratory Society. Am J Respir Crit Care Med. 2002; 166(4):518-624.

32. ERS Taskforce, Palange P, Ward SA, Carlsen KH, Casaburi R, Gallagher CG Recommendations on the use of exercise testing in clinical practice. Eur Respir J. 2007;29(1):185-209.

33. A Chetta, P Tzani, E Marangio, P Carbognani, A Bobbio, D Olivieri. Respiratory effects of surgery and pulmonary function testing in the preoperative evaluation. ACTA BIOMED 2006; 77; 69-74.

34. Hasukic S, Mesic D, Dizdarevic E, Keser D, Hadžiselimovic S. Pulmonary function after laparoscopic and open cholecystectomy. SurgEndosc 2002;16: 163-165.

35. Schwenk W, Bohm B, Will C, Junghans T, Grundel K, Muller JM. Pulmonary Function Following Laparoscopic or Conventional Colorectal Resection. Arch Surg. 1999; 134:6-12

36. Freeman JA, Armstrong IR. Pulmonary function tests before and after laparoscopic cholecystectomy. Anaesthesia 1994;49:579-582.

37. Cooper BG. An update on contraindicatio ns for lung function testing. Thorax 2011; 66:714 723 .

38. Lao L, Weng X, Qiu G, Shen J. The role of preoperative pulmonary function tests in the surgical treatment of extremely severe scoliosis. Journal of Orthopaedic Surgery and Research 2013 8:32.

39. Yin S, Tao H, Du H, Feng C, Yang Y, Yang W. Postoperative pulmonary complication following posterior spinal instrumentation and fusion for congenital scoliosis. PLoS ONE, 2018; 13(11): e0207657.

40. Zhao Y, Leng S, Li D, Feng S, Wang Z, Tao C. Pulmonary function impairment predicted poor prognosis ofpatients with hepatocellular carcinoma after hepatectomy. Oncotarget, 2017;8(43):75326-75335

41. Christensen EF, Schultz P, Jensen OV, Egebo K, Engberg M, Grøn I, Juh B.Postoperative pulmonary complications and lung function in high-risk patients: a comparison of three physiotherapy regimens after upper abdominal surgery in general anesthesia. Acta Anaesthesiol Scand. $1991 \mathrm{Feb} ; 35(2): 97-104$

42. Akhan SE, Baysal B.Laparotomy or laparoscopic surgery? Factors affecting the surgeons choice for the treatment of ectopic pregnancy.Arch Gynecol Obstet. 2002 Apr;266(2):79-82

43. Janssens JP. Aging of the respiratory system: Impact on pulmonary function tests and adaptation to exertion. Clin.Chest. Med., 2005;26(3): 469-84.

44. Knudson RJ, Lebowitz MD, Holberg CJ, Burrows B. Changes in the normal maximal expiratory flow-volume curve with growth and aging. Am. Rev. Respir.Dis., 1983;127: 725-34.

45. Pruthi N, Multani NK. Influence of Age on Lung Function Tests. Journal of Exercise Science and Physiotherapy, 2012;8(1): 1-6.

46. Harms CA. Does gender affect pulmonary function and exercise capacity?.Respi PhysiolNeurobiol. 2006 Apr 28;151(2-3):124-31.

47. Ford ES. The epidemiology of obesity and asthma. J Allergy Clin Immunol 2005;11:897-909.

48. Chen Y, Dales R, Tang M, Krewski D. Obesity may increase the incidence of asthma in women but not in men: longitudinal observations from the Canadian national population health surveys. Am J Epidemiol2002;155:191-97.

49. Chen,Y, Rennie D, Cormier Y, Dosman, J. Sex specifiity of asthma associated with objectively measured body mass index and waist circumference: The Humbolt study. Chest. 2005;128:3048-54

50. Guerra S, Sherrill D, Bobadilla A, Martinez F, Barbee RA. The relation of body mas index to asthma, chronic bronchitis, and emphysema. Chest. 2001;122(4):1256-63.

51. McLachlan CR, Poulton R, Car G. Adiposity, asthma, and airway inflmmation. J Allergy Clin Immunol. 2007;119: 624-39.

52. Chen Y, Dales R, Krewski D, Briethaupt K. Increased effects of smoking and obesity on asthma among female Canadians: the national population health survey, 1994-1995. Am JEpidemiol. 1999;150:255-62.

53. Jenkin SC, Moxha J. The effects of mild obesity on lung function. Respir Med. 1991;85:309-311

54. Sutherland TJT, Cowan JO, Goulding A, Young S. The association between obesity and asthma: interactions between systemic and airway inflmmation. Am J Respir Crit Care Med. 2008:178:469-75.

55. Collins, LC, Hoberty, PD, Walker, JF, et al The effect of body fat distribution on pulmonary function tests. Chest. 1995;107:1298-1302.

56. Al Ghobain $\mathrm{M}$. The effect of obesity on spirometry tests among healthy nonsmoking adults. BMC Pulmonary Medicine. 2012;12:10.

57. Watson RA, Pride NB. Postural changes in lung volumes and respiratory resistance in subjects with obesity. J ApplPhysiol 2005; 98: 512-517.

58. Richard L, Mary-Magdalene U. Nzekwu. The Effects of Body Mass Index on lung volumes. Chest. 2006;130;827-33.

59. Cheryl M. Salome, Gregory G. King and Norbert Berend: Physiology of obesity and effects on lung function. J Appl Physiol. 2010;108:206-11.

60. Biring M, Lewis M, Liu JT, Mohsenifar Z. Pulmonary physiologic changes of morbid obesity. Am J Med Sci. 1999;318:293-97.

61. Sin DD, Jones RL, Man SFP. Obesity is a risk factor for dyspnea but not for airflw obstruction. Arch Intern Med. 2002;162:1477-81

62. Andrew J, Debbie B, Ali B. The Association of Body Mass Index with Airway Obstruction in Non-Asthmatics: Implications for the Inaccurate Differential Diagnosis of Asthma in Obesity. Canadian Journal of Respiratory Therapy 2011;47:2

63. Fahy BG, Barnas GM, Nagke SE, Flowers JL, Njoku MJ, Agarwal M. Changes in lung and chest wall properties with abdominal insufflation of carbon dioxide are immediately reversible. AnesthAnalg, 1996;82:501-505.

64. Ford GT, Witelaw WA, Rosenal TW. Diaphragm function after upper abdominal surgery in humans. Am Rev Respir Dis, 1983;127: 431-436.

65. Khetarpal R, Bali K, Chatrath V, Bansal D. Anesthetic considerations in the patients of chronic obstructive pulmonary disease undergoing laparoscopic surgeries. Anesth Essays Res. 2016; 10(1):7-12.

66. Miller TE, Raghunathan K, Gan TJ. State-of-the-art fluid management in the operating room. Best Pract Res Clin Anaesthesiol. 2014; 28(3):261-73.

67. Oh TK, Park IS, Ji E, Na H-S (2018) Value of preoperative spirometry test in predicting postoperative pulmonary complications in high risk patients after laparoscopic abdominal surgery. PLoS ONE 13(12): e0209347.

68. Tajima Y, Tsuruta M, Yahagi M, Hasegawa H, Okabayashi K, Shigeta K, et al. Is preoperative spirometry a predictive marker for postoperative complications after colorectal cancer surgery? Jpn J Clin Oncol. 2017; 47(9):815-9.

69. Clavellina-Gaytan D, Velazquez-Fernandez D, Del-Villar E, Dominguez-Cherit G, Sanchez H, Mosti M, et al. Evaluation of spirometric testing as a routine preoperative assessment in patients undergoing bariatric surgery. Obes Surg. 2015;25(3):530-6.

0. Huh J, Sohn TS, Kim JK, Yoo YK, Kim DK. Is routine preoperative spirometry 
necessary in elderly patients undergoing laparoscopy-assisted gastrectomy? J Int Med Res. 2013;41(4):1301-9.

71. Rock P, Rich PB. Postoperative pulmonary complications. Current Opinion in Anesthesiology. 2003; 16(2):123-31.

72. Lai Y, Wang X, Li P, Li J, Zhou K, Che G. Preoperative peak expiratory flow (PEF) for predicting postoperative pulmonary complications after lung cancer lobectomy: a prospective study with 725 cases. J Thorac Dis 2018;10(7):4293-4301. 